\title{
CHANGING HIGHER EDUCATION AND WELFARE STATES IN POSTCOMMUNIST CENTRAL EUROPE: NEW CONTEXTS LEADING TO NEW TYPOLOGIES?
}

\author{
MAREK KWIEK
}

\begin{abstract}
The paper links higher education reforms and welfare states reforms in postcommunist Central European countries. It links current higher education debates (and reform pressures) and public sector debates (and reform pressures), stressing the importance of communist-era legacies in both areas. It refers to existing typologies of both higher education governance and welfare state regimes and concludes that the lack of the inclusion of Central Europe in any of them is a serious theoretical drawback in comparative social research. The region should still, after more than two decades of transition and heavy international policy advising, be viewed as a "laboratory of social experimentation". It is still too risky to suggest generalizations about how Central European higher education and welfare systems fit existing typologies. Consequently, the "transition" period is by no means over: it is over in terms of politics and economics but not in terms of social arrangements. Both higher education and welfare states should be viewed as "work in progress": permanently under reform pressures, and with unclear future.
\end{abstract}

Keywords: Central Europe; globalization and welfare reforms; higher education reforms; international policy-making; university governance.

\section{Higher education debates, public sector debates}

Debates on the future of higher education in postcommunist Central European economies are closely linked to much wider debates on the future of the public sector and of the state provision of public services in general (Orenstein, 2009; Häusermann, 2010; Rothgang et al., 2010). In the acme of the development of traditional Keynesian postwar welfare state regimes in Europe, it was the state-rather than the market—-that was deeply involved in the economy and in the protection of nation-state citizens against the potential social evils of postwar capitalism (Hurrelmann et al., 2007a). As Vito Tanzi highlighted in his recent book on Governments versus Markets. The Changing Economic Role of the State, the role of the state in the economic development is the fundamental question:

How wide and deep such a role be in a market economy? What should the state do? How much should be left to the market and to the free economic decisions of individuals or groups of citizens? How should the state perform its role? (Tanzi, 2011, ix) 
The role of the state in general means also, in a context of interest to us here, its role in the provision of both higher education services and welfare state services. It was in Central Europe, exposed to the influences of global organizations in redefining their national welfare policies following the fall of communism in 1989 that the direct link between the new "effective" state on the one hand (with "downsizing" of the public sector) and higher education policies on the other, was very much visible. With almost no exceptions, higher education in the 1990s was one of the lowest priorities in European transition countries, with chronic underfunding of their universities as a permanent feature. Social policies for the ten accession countries which joined the European Union in 2004, generally promoted and praised in subsequent accession countries' reports by the European Commission, were not exactly "European" policies rooted in a "European social model"1. On the contrary, as Zsuzsa Ferge (2001, p.129) showed (with respect to policies actually being implemented in the healthcare, pensions, higher education and other public sectors), these policies were largely neoliberal. It is in Central Europe that educational policies, and consequently the future of public universities, may be going hand in hand with changing welfare policies, as in the traditional World Bank formulation of the "third wave of privatization" where changes in (higher) education follow changes in the two other major claimants on welfare state resources: healthcare services and public pensions systems (Rama, 2000; see the ideas of "redefining the state", "shrinking the state", "dismantling democratic states", and "transforming the state"-Spulber, 1997; Feigenbaum et al., 1998; Suleiman, 2003; Hurrelmann et al., 2007a).

\section{“Back to Europe?” Transition, accession, and beyond}

Higher education in Central Europe is one of those social areas that have been exposed to various reform attempts following 1989. Reforms in higher education in the region throughout the last two decades were intended, implicitly or explicitly, to bring Central European academics and students back into what was regarded to be the European academic community. Reform attempts were born out of specific, regional postcommunist concerns mixed with concerns of higher education developments observed in Western Europe (with a powerful limitation, though: as Brunsson (2009) argues with respect to organizations, "reform is not equivalent to change. An organization may undergo several reforms and emerge with little change. During a certain limited time, some people may merely describe the organization in a new way, with no other consequences for the organization's activities"). Clearly, national and regional reference points in higher education reforms were accompanied by European reference points, especially when the Bologna Process started at the turn of the

\footnotetext{
${ }^{1}$ The "selling" of the EU accession to electorates in the East and in the West was crucial. As Nicolas Barr (2005, p. 16) summarized the political pre-conditions for the accession: policies needed to be both parsimonious and generous, depending on the electorates. It was necessary to find "a meeting ground between two sets of political imperatives": "were the accession arrangements sufficiently parsimonious for EU politicians to sell them to their electorates? A settlement too generous to the transition countries risked rejection by the existing EU members. Were the proposed arrangements sufficiently generous that politicians in the accession countries could sell them to their electorates?"
} 
century and when this European intergovernmental initiative started to be used in national contexts in the region as a justification for further reforms.

The overall trajectory of wider policy changes in Central Europe is a special case in the second half of the $20^{\text {th }}$ century: in no other part of the world a similar successful, massive transformation from command-driven economies to market-driven economies was undertaken by ten neighboring countries, all more or less desperately seeking to "catch up with the West" (or to be "back to Europe", as the title of Karen Henderson's book runs) after having been under communist regimes for more than forty years). ${ }^{2}$ The countries in the region wanted to join as soon as possible (both politically and economically) Western Europe, with its standards of democracy and its levels of material affluence. What later became known as the "transition" (Barr, 1994) was actually a peaceful revolution in economic and public service sectors, including the higher education sector. ${ }^{3}$

During the last twenty years, the countries in the region were generally lumped together, first as "transition" economies (Barr, 1994), then as "accession" economies, and finally, following the 2004 and 2007 waves of the European enlargement, as "new EU entrants" (Barr, 2005; Lane \& Myant, 2007; Kogan et al., 2011). While in the transition period of the 1990s, models of reforming all public services, including higher education, were coming mostly from the World Bank, in the pre-accession period of the 2000s and especially after the entrance into the EU, the role of both intergovernmental European processes (the Bologna Process) and supranational European processes (the implementation of the Lisbon 2000 Agenda) has been gradually growing. Today, the role of the European Commission and various strands of EU funding, especially EU structural funds, is fundamental for national higher education reforms in the region.

\section{Communist-era legacies}

Historically, the university model prevalent in the region in the pre-war period (before 1939) was the Humboldtian one, even though in some countries, for example, Romania, there were strong influences of the Napoleonic model. Current university models in the region, though,

\footnotetext{
${ }^{2}$ See especially several major book contributions on structural reforms of the transition period "in the making", mostly from the 1990s: by Marie Lavigne; Olivier Blanchard, Kenneth A. Froot and Jeffrey D. Sachs; Janice Bell; John Pickles and Adrian Smith; John L. Campbell and Ove K. Pedersen; John Williamson; Joan M. Nelson, Charles Tilly, and Lee Walker. A separate research strand is the "institutional design" literature on postcommunist transformations from the 1990s, including books and papers by Jon Elster, Claus Offe, Ulrich K. Preuss and Robert E. Goodin.

${ }^{3}$ Nicholas Barr shows the difference of priorities between the transition countries (especially in the 1990s) and countries of Western Europe in the following way: the aim of public policy, including social policy, is to maximize people's well-being, which in turn "depends both on economic growth ... and on security". An overemphasis on one or the other element is counterproductive (Barr, 2005, p. 26): "social policy needs to assist the optimal balance between the two - a balance that will differ across countries. 'Catching up' is a major thrust of policy in the former communist countries, suggesting greater emphasis on growth; electorates in the richer countries of Western Europe might choose a somewhat different balance". In the 1990s, the economic aspect of the people's well-being-associated with economic growth, which at that time in most countries of the region was marginal or negativewas of key importance.
} 
cannot be easily referred to as having clear Western European, i.e. French or German or AngloSaxon (Newmanian) features. Depending on the aspect of university functioning under consideration, they can be paradoxically termed both Humboldtian and Anglo-Saxon, just as currently reformed welfare state regimes in the region share characteristics of both conservative and strongly corporatist regimes and Anglo-Saxon liberal regimes (Esping-Andersen, 1990).

New models of higher education governance, as new models of public sector reforms in general, are still only emergent in the region (for early theoretical formulations of public sector reforms in postcommunist economies, see especially Nolan, 2001; Lane, 1996; Lane, 1993). Nonetheless, some scholars have already discussed a potentially distinct "Central European knowledge production model" and a "post-communist welfare state model" (Kwiek, 2011; Aidukaite, 2009; see Gornitzka \& Maassen, 2011 on a unique "Nordic Model"). ${ }^{4}$ Polish reforms are a good example of a time sequence in reforming public services in general in the region: while pension and healthcare reforms were initiated in 1999, significant higher education reforms started only a decade later, in 2008-2011. As in many other parts of both Western and Central Europe, higher education reforms are often viewed today as "incomplete" (as organizations can be viewed as "incomplete" and still not "true", see Brunsson, 2009), and as leading to further waves of reforms, especially in the context of the financial crisis in Europe (Kwiek, 2012b).

In the communist period, the economy, welfare services, and higher education had specific features. Communist-era welfare states were unique, and, similarly, communist-era higher education systems were unique. Following Mateju et al. (2007), we can summarize them as having six core characteristics that need to be taken into account to understand the change dynamics in post-communist countries today: (1) higher education was heavily centralized and part of the central planning system; the overall number of students and their allocation to major fields of study and programs were decided centrally. (2) There was an intense bureaucratic control over the entire system, which included balancing the number of graduates with the number of jobs, displaced job competition, and educational credentials being more important in job allocation than actual knowledge, skills, and competencies. (3) Curriculum guidelines, research goals, and requirement for filling teaching positions were defined and closely monitored by the communist party. (4) Traditional university education was a unitary system that lacked short bachelor's programs. (5) Decisions about the number of students admitted and enrollment procedures were based on central guidelines and quotas set by the communist party for controlling the proportions of students of various social

\footnotetext{
${ }^{4}$ In analyzing a (possible, emergent) "Central European knowledge production model", it would be useful to go beyond the "varieties of capitalism" typology (Central and Eastern Europe does not fit its traditional formulations) and beyond "the three worlds of welfare capitalism" typology (the region does not fit it so far either, see Hall \& Soskice, 1991; Esping-Andersen, 1990; Lane \& Myant, 2007). "Postcommunist universities"-as a substantial component of the "postcommunist welfare state"-in "postcommunist capitalist economies", after two decades of transformations, are still in the making. It would be also useful to go beyond other established typologies of the welfare state, for instance, "families of nations" (Castles, 1993a; Castles \& Obinger, 2008). The issue of the "specificity" of the regional knowledge production and specificity of regional welfare regimes seems to be highly underresearched, despite several recent attempts (Aidukaite, 2009; Inglot, 2008; Cerami, 2006; Cerami \& Vanhuysse, 2009; Lane, 2007a; Kwiek, 2011).
} 
backgrounds. (6) The funding of universities was entirely dependent on the government, based on incremental budgeting (Mateju et al., 2007, p. 374).

Perhaps most importantly, education under socialism had very specific tasks to perform:

Socialist leaders viewed education as a crucial economic and political instrument to foster economic development and to politically indoctrinate citizens, and therefore placed the entire education system under firm state control. Educational planning became increasingly differentiated, regulating not only student quotas and resource allocation, but also the types of educational programs and specializations, curricula, and the content of textbooks, as well as regulating the flow of individuals through the education system and afterword into the labor market. Individual preferences bore little or no influence on the available educational options, which were constrained by the strict limits defined by planning agencies (Noelke \& Müller, 2011, p. 16; see also Kogan et al., 2011; Szczepanski, 1974).

Haggard and Kaufman (2008, p. 4) summarize the welfare state model in general in the region, with implications for higher education systems throughout the communist world, as follows:

In Eastern Europe, social policy was anchored by an overarching employment guarantee, but also by a strong commitment to education and training, universal healthcare and pensions, and family allowances. These commitments began as occupational ones but were transformed over the postwar period into universal citizenship rights.

Communist-era legacies still powerfully influence higher education and welfare state access and provision across the region. Reforms in both areas have to profoundly look forward and look back, and no country in the region attempted to use a "big bang" approach in either of the social areas. Financial entitlements from the communist period in public pensions are as important as academic beliefs and attitudes in the university sector, deeply rooted in the communist period.

\section{Higher education in the transition period}

Leszek Balcerowicz, the founding father of Polish economic reforms through a famous "shock therapy" of 1990, never used the word "higher education" in any context in his seminal book Socialism, Capitalism, Transformation (1996). ${ }^{5}$ Not surprisingly, also Jeffrey Sachs in his Poland's Jump to Market Economy (1994) never used the word. In the transition period of the 1990s, there was generally very limited interest in universities and their performance, or in university reforms leading to their better performance: higher education

\footnotetext{
${ }^{5}$ As Orenstein $(2008$, p. 25) reminds, "shock therapy was intended to produce a rapid and painful adjustment to a market economy while dismantling many of the institutions of communism. Central elements of the shock therapy strategy were speed and simultaneity in enacting these changes". And as Sachs argued "you can't cross a chasm in two jumps". See "political consequences of economic reforms" in Przeworski (1991, p. 187) and his warnings that with weakened democracy, reforms may become politically destabilizing: "authoritarian temptations are inevitable" and "doubts, oppositions, insistence on procedures appear to be symptoms of irrationality".
} 
and research and development systems were missing from the general picture of Polish transformations. Most prominent political figures involved in Polish economic reforms hardly mention reforms of both systems at all. Poland was not an exception, though: the lack of higher education reforms in the early 1990s was prevalent in Central Europe, perhaps partly due to overwhelming Western views that communist educational systems did not need any substantial transformations, in contrast to economic systems and political systems which needed fast and deep changes. It needs to be added, by way of justification, though, that the 1990 s in the region meant creating capitalism from scratch, creating "the very fundamentals of capitalism"; not surprisingly, "in Eastern Europe, both markets and private enterprises were virtually non-existent for about 40 years" (Elster et al., 1998, p.157; see also Haggard \& Kaufman, 2008, p. 181). In postcommunist Central European economies, perhaps most of all in Poland, privatization in several social areas is no longer a vision; it is a reality (for "internal" and "external" privatization in higher education, see Kwiek, 2010).

And in the meantime - throughout the 1990s-higher education landscape in Western Europe was undergoing profound transformations, most often according to governmental plans and national strategies. Systems in both parts of Europe were dramatically changing in the 1990s but transformations in Central Europe were often unplanned, chaotic, uncoordinated, profit-driven, intuitive, and fragmentary; transformations in Western Europe in the 1990s consisted much more of government-coordinated changes, resulting from governmentdesigned national strategies and emergent revised national policies (Kwiek, 2012b).

\section{Globalization and welfare state}

Globalization powerfully affects the welfare state futures and higher education futures (Kwiek, 2006; Kwiek, 2009). Challenges of globalization, which have been present in Europe for at least three decades and which are here to stay, to all public sector services are also accompanied by powerful demographic challenges. As Leibfried and Mau emphasize in their introduction to a recent three-volume Welfare States: Construction, Deconstruction, Reconstruction (2008, xii), since the oil crises in the mid-1970s,

[t]he welfare state has been grappling with deep-rooted challenges. A series of major economic, social and political shifts - such as globalization, demographic pressures, individualization, persistent high unemployment, greater social diversity and fiscal scarcity - have raised the question: How sustainable is the welfare state in the long run?

In general terms, Europe is witnessing more general attempts at a reformulation of the post-war social contract which gave rise to the welfare state as we know it (with public higher education as we know it). We argue here for a strong thesis according to which Europe is facing the simultaneous renegotiation of the postwar social contract concerning the welfare state in Europe and the accompanying renegotiation of a smaller-scale, by comparison, modern social pact between the university and the nation-state (for a full picture, see Kwiek, 2005). ${ }^{6}$ The renegotiation of the (nation) state/university pact is not clear outside of the

${ }^{6}$ As Stephan Leibfried and colleagues argue in their presentation of an analytical framework for the whole "Transformations of the State" Palgrave book series, "the state today operates in a radically 
context of the changing welfare state contract, as state-funded higher education formed one of the bedrocks of the European welfare system in its major forms, and state-funded higher education remains one of its foundations. Education, including higher education, is viewed in this paper (following Kwiek, 2013a; Kwiek, 2007) as a significant component of the traditional welfare state. We are thereby following here Joseph E. Stiglitz's Economics of the Public Sector, Nicholas Barr's Economic Theory and the Welfare State and others. Transformations to the state, and the welfare state in particular, affect-both directly and indirectly—public higher education systems in Europe.

The question of university reforms is about "normative" and "operational" modes of higher education being in tune or out of phase across European systems (in Becher and Kogan's terms: these are the two major dimensions to study higher education, Becher \& Kogan, 1980):

As long as the normative and operational modes are in phase with one another, the system as a whole can be said to be in dynamic equilibrium - if not in harmony, then at least in a state of balanced tension. But when the two modes become significantly out of phase, some kind of adjustment is necessary to avoid breakdown and to restore the possibility of normal functioning (Becher \& Kogan, 1980, p. 17).

Currently, the two modes across Europe are viewed to be out of phase (mostly by policymakers, the society at large, or sometimes both; much less often by the academic community). Therefore reform pressures are strong, as "a predisposition for change is created when the normative and operational elements at any level become significantly out of phase. The situation will usually give rise to some appropriate change in belief or practice designed to restore normal functioning" (Becher \& Kogan, 1980, p.120).

Generally, discussions about the future of the institution of the university so far have not accompanied huge social transformations of the last one hundred years, and, have not accompanied the emergence of postwar welfare states in Western Europe. However, today, these discussions invariably accompany the transition to new forms of economy and society-simplifying and selecting only one item from among a plethora of descriptions in sociology and political sciences-knowledge-driven economy and knowledge-based society (Stehr, 2002; Foray, 2006). It is hardly possible to view the transformations to the institution of the university without viewing the transformations to the social fabric in which it has been embedded. The modern university, the product of modernity, is under the very same pressures as other modern institutions and other social arrangements. The possible decline of the historical exceptionality of the modern institution of the university (at least

new environment - multinational corporations, accountable only to their shareholders, gain bargaining power vis-à-vis the state's democratic institutions by threatening to relocate production. Capital mobility restrains state control over monetary policy. Competitive pressure to lower tax rates undermines the state's resources and has the potential to unleash financial crises that, in turn, trigger cuts in welfare spending". What they term "the golden-age constellation" of the four components (the territorial state, the constitutional state, the democratic welfare state and the interventionist state) is threatened: "different state functions are threatened to a greater or lesser degree, and subjected to pressures for internationalization of varying intensity" (Hurrelmann et al., 2007b, p.7, 9). Educational policies are one of the dimensions of the "golden-age constellation" under renegotiations today (Kwiek, 2005). 
compared with the post-war period) results from the same pressures as those affecting other modern institutions-including the institutions of the state, its agencies and public services, international or supranational institutions, and institutions of the private corporate world (see Held \& McGrew, 2007; Hay et al., 2006; Djelic \& Quack, 2012; Campbell, 2004). These pressures are often lumped together as either "globalization" or "knowledge economy", both closely interrelated.

As known in organizational studies, reforms need problems and reforms need solutions: a supply of problems needs to be complemented with a supply of solutions, preferably more or less ready solutions. As Brunsson argues:

Problems are not enough to trigger administrative [organizational] reforms. A supply of ideas for solutions is also needed, solutions which deal with organizational structures, processes, and ideologies and which differ from the solutions presently practiced. Solutions, like problems, can be fabricated by those who wish to pursue reforms; but the task of reformers is easier if a supply of more or less ready solutions is available. Solutions can exert an attraction on those who pursue reforms and on those who are affected by them (Brunsson, 2009, p. 96).

These processes, if not directly result from globalization, are at least intensified by it. The question debated today is not whether recasting the European welfare state has come to be seen as necessary by the national governments of most affluent Western democracies, international organizations, and global organizations and development agencies. The question rather is why it is seen as necessary, and the answers include globalization-related economic integration, demographic changes, changes in societal norms, changes in family patterns etc. As Maurizio Ferrera explained a decade ago the fundamental logic that is guiding policy solutions to the reform processes of the welfare state today: "system-wide searches for novel, economically viable, socially acceptable and politically feasible policy solutions are underway" (Ferrera, 2003, p. 596). Solutions should thus be both fundable and socially and politically acceptable. Transition from industrial to post-industrial societies has "fundamentally challenged social policy arrangements of Western welfare states. ... In particular, the state is no more able (or willing) to protect citizens against new social risks. ... The effects of globalization on the development of welfare state are unclear. We do not yet know the specific extent to which globalization will alter socio-political systems and indeed change the course of the entire welfare state models", as Sipilä et al. (2009, p. 181) emphasize.

Apart from a large and increasing body of academic work (by, for instance, Nicholas Barr, Giuliano Bonoli, Peter Taylor-Gooby, Fritz W. Scharpf \& Vivien A. Schmidt, Torben Iversen, Jonas Pontusson, Paul Pierson and others), there is also a vast amount of conceptualizations of pension reforms emerging in the last ten years from various non-academic fields, closely related to policymaking - especially in the work of the OECD and the World Bank experts. The link between academic works and non-academic works is weak in the area, as it is weak in the case of higher education reforms. Probably, at the moment, no other academic research center can compete with the two organizations in the long-term commitment to the study of pension reforms and the identification of practical solutions to problems of aging populations. New concepts emerge, statistics on a global scale are analyzed in detail, best practices from countries already involved in reforms are compiled and, at the same time, 
developing countries can count on the combination of the expertise and financial support (in the form of both technical assistance and loans). For most developing countries, at the moment, there seems to be no alternative to packages of technical assistance in reforms implementation combined with funding mechanisms (see Jakobi et al., 2010a on agendasetting and policy diffusion from international organizations, and Woodward, 2009; Martens \& Jakobi, 2010a on the OECD as an actor in international politics). Central European countries used to be experimental fields for the diffusion of global ideas mostly in the 1990s.

\section{International players in policy-making in Central Europe}

In different periods following the collapse of communism, different international actors were the major players in national educational, social and welfare policy making processes, including higher education policy processes. The three international organizations of greatest influence in the region were the World Bank, the OECD and, especially in the preaccession period of the 2000s, the European Union. Other global and regional international organizations, such as e.g. the ILO (International Labor Organization), the Council of Europe, the International Monetary Fund or various UN agencies (such as the UNDP), were of much lesser importance, except for some countries (such as the Council of Europe in the post-conflict countries emergent from the former Yugoslavia). In Central Europe generally, "policy thinking and advice received differed in each country, often idiosyncratically, explaining a large part of the seemingly unsystematic differentiation in countries on more or less equivalent paths towards Europe" (Orenstein \& Haas, 2005, p. 143).

The role of the OECD in national policy debates and national reform projects in higher education in Central Europe, especially in Poland, was very important (as it is important globally: see Martens, 2007; Martens \& Jakobi, 2010b). A significant part of the "global script" (Gornitzka \& Maassen, 2011) in higher education policy (rather than in social policies where the message has been consistently conveyed by the World Bank) in Central Europe has been conveyed by the OECD and its country reports on higher education. In Poland, interesting examples of international organizations' discourse on the reforms of higher education include also World Bank's seminal reports. Policymakers' expectations from both OECD and World Bank reports have been very high; this concerns especially the 2007 OECD Review of Tertiary Education. This review was translated into Polish and widely used in policy debates about reforms, especially as an outsider's (international) justification of the wave of 2008-2011 higher education reforms.

Probably the highest international influence on national policies in higher education came from the "European agenda" in higher education, though, especially in the areas most explicitly linked to the Bologna Process and its requirements in the 2000s. Magna Charta Universitatum of 1986 and the Bologna Declaration of 1998 were signed by most countries from the region. A new "open method of coordination" made the diffusion of higher education policies in Central Europe much more effective (Gornitzka, 2007). Generally, the initial enthusiasm of Central European countries (and their high ranks in the implementation charts provided in subsequent Trends reports) gave way to current implementation problems in several areas (leading first to self-declared "red lights" in the 2009 Bologna Stocktaking Report implementation charts; see also the Trends 2010 report on Central Europe generally). 
In contrast, in terms of preparations to the UE accession in the first half of the 2000s, in economic policies rather than in higher education policies it was the World Bank that was setting the agenda for Central European countries:

The World Bank tended to dominate the agenda, coordinating with the EU on issues of preparation for accession. ... [E] ast-central European countries found themselves part of a social policy discourse that primarily included their governments, the EU, and the World Bank, with the latter doing much to set the agenda for these discussions (Orenstein \& Haas, 2005, p. 146).

Between 1994 and 2004, eleven postcommunist countries partially privatized their pension systems - and the case of pension reforms shows that "transnational actors had a fundamental influence on the social-policy agenda in postcommunist countries after the mid1990s. They exercised this influence in many other areas as well, setting standards for health reform and reshaping unemployment-benefit systems and many other programs" (Orenstein, 2008 b, p. 86-87). Higher education in the 1990s and until mid-2000s was one of those social areas in which this influence was marginal, except for Hungary where the influence of the World Bank, on and off, was higher than anywhere else in the region.

The role of the European Commission in shaping higher education policies in Poland was relatively unimportant throughout the 1990s when Poland was only vaguely considered as a future member state and when the "modernization agenda for universities" was still to emerge in Europe. The Commission's role became very important in all social areas, including higher education, at least at a declarative level, in the 2000s, prior to the EU Enlargement in 2004 (from a European perspective, see: Gornitzka, 2007; Maassen \& Olsen, 2007; Kwiek \& Maassen, 2012). Poland in the 2000s was joining the emerging European research and higher education areas and was among the signatory countries of the Bologna Declaration in 1999. The role of the EU accession conditionalities for changes in all public services became of critical importance in the early 2000s: they were used, in general, as supporting a neo-liberal social model rather than the so-called "European Social Model", in its different variants. ${ }^{7}$ In the early 2000s, the EU accession countries, Poland included, were much more praised by the European Commission for their social reforms leading to neoliberal solutions than for reforms potentially leading to any traditional Western European social arrangements (see Polish annual reports to the EC prior to 2004). While most public sector services were becoming more marketized, including pensions and healthcare, public higher education was using market forces in one dimension only: more fee-paying part-time students bringing more non-core non-state income. This was one side of the privatization process, the other being the growth of fee-based private higher education. More marketlike solutions in university governance or public research funding, university links with the economy or the commercialization of research were not introduced until the reforms of 2008-2011 (Kwiek, 2010; Kwiek, 2013b). International and supranational agendas in higher

\footnotetext{
${ }^{7}$ Various policy reforms in various CEE countries in the 1990s are examples of what Simmons, Dobbin and Garrett $(2008$, p. 7) term "international policy diffusion": it occurs "when government policy decisions in a given country are systematically conditioned by prior policy choices made in other countries (sometimes mediated by the behavior of international organizations or private actors and organizations". On policy diffusion in educational policies, see Martens \& Jakobi, 2010a).
} 
education reforms mattered in Poland, in different periods to different degrees. Apart from the OECD, important international influence on national policies in higher education was exerted by the European agenda, especially in teaching-related areas linked to the Bologna Process and its expectations throughout the 2000s. The initial enthusiasm for, and high ranks in the scores of the implementation of the Bologna Process, gradually gave way to implementation problems, though. Nonetheless, throughout the 1990s and the early 2000s, higher education was one of those public sector areas where the World Bank's influence in Central Europe was marginal. Recently, the notions of knowledge economy, universityenterprises cooperation and economic competitiveness are often invoked in official rationales accompanying Polish reforms (from a wider perspective, see Kwiek \& Maassen, 2012; Kwiek, 2012c).

Transformations of Polish universities as institutions in the 1990s followed in general Robert E. Goodin's models of social change. Goodin (1996, p. 24) distinguishes between three basic ways in which social institutions might arise and change over time: by accident: "what happens just happens", by evolution: the survival of the "better fitted" to their environments, and by intentional intervention: "the change might be the product of the deliberate interventions of purposive, goal-seeking agents". His conclusions fit perfectly the Polish case: "any actual instance of social or institutional change is almost certain to involve a combination of all three of these elements". Indeed, in the face of massive social, political and economic transformations of an unprecedented scale in the postwar history of Europe, universities were changing by accident, evolution, and intention, with the emphasis on the first two models: accident and evolution.

Intentional interventions in higher education policy, on the part of national governments, were rare, and there was a set of overarching principles guiding transformations in the university sector: institutional democracy, institutional autonomy, and academic freedom, all regained after the period of communism. These can be regarded as "desirable principles of institutional design" and "principles with deeper moral resonance" (Goodin, 1996, p. 39). But after general guiding principles, no further elaborate institutional designs followed. The state seemed to have no clear ideas about how to deal with disintegrating higher education institutions, characterized by radically decreasing academic salaries, brain drain of both academics and top graduates, collapsing system of research funding, etc. which led to what we have termed elsewhere "the deinstitutionalization of the research mission" in Polish universities in the times of educational expansion (Kwiek, 2012a). There were other social and economic concerns, of more critical importance: suffice it to say that the annual inflation rate in Poland in the early 1990s was in the range of a few hundred percent.

\section{Pressures on university reforms and pressures on welfare state reforms}

Higher education systems in Central European countries have faced generally the same challenges as those in other OECD countries, but in the double unfriendly context of the need to radically change the structure (and focus) of their former educational systems while operating in tough fiscal and economic environments (Barr, 2005). The massification of higher education in Central Europe occurred with a long delay of two-three decades compared with Western European systems, but it took place in a specific context of public 
underfunding for old public institutions and the emergence of new private institutions opening their doors to hundreds of thousands of new students, with mostly non-traditional socio-economic backgrounds (on the trade-off between access and quality, see Kwiek, 2013b). ${ }^{8}$ So higher education challenges in the region have been generally the same as in Western Europe, but the economic context of massification processes was vastly different. One of the policy answers in several countries in the region was privatization of higher education.

In analyzing reforms, there is a useful distinction drawn by institutional studies between "changes within fairly stable institutional and normative frameworks" and "change in the frameworks themselves" (March \& Olsen, 2006, p. 14). Central European transformations in higher education in the early 1990s clearly belong to the radical, latter, while transformations in the 2000s are more of the incremental, former type. But in the Polish case the most recent wave of reforms could have a potential of changing again "the frameworks themselves". It is too early to have solid empirical evidence, though; and some crucial regulations accompanying the amended law are still in the making. Additionally, as in all reforms (Brunsson, 2009, p. 9), "the impact of reformers on reforms is more limited than appears from the reformers' descriptions of reforms. The content of a reform is determined more by societal institutions and public discourse than by local 'actors', whether individuals or organizations".

The level of public dissatisfaction with universities in Central Europe is high but not critical. The media and the governments tend to present universities in dark colors and radical policy changes are suggested (rather than, so far, radical reforms are actually implemented). Public trust in higher education has been eroding for a long time, and policymakers are seeking new governing rules in response to this public dissatisfaction and in view of transformations changing higher education funding and governance throughout Western Europe. Unlike at the beginning of the $19^{\text {th }}$ century, universities as institutions are not threatened with falling into oblivion (Delanty, 2001; Kwiek, 2006)—but they are viewed in recent higher education strategies throughout Central Europe, echoing their harsh criticism in European-level documents, as in need of radical reforms. The alarming tone of governmental statements about Polish universities is not different from the alarming tone of European Commission's communications about European universities in general-but the former is clearly much more justified (on the "modernization agenda of European universities" from a comparative international perspectives, see Kwiek \& Maassen, 2012).

Transformations of postcommunist universities in Central Europe can be viewed as resulting from several powerful, interrelated, internal and exogenous, pressures. First, there were internal pressures to continue with rules and organized practices inherited from

\footnotetext{
${ }^{8}$ As Nicholas Barr argued, in EU accession countries, the governments were caught between conflicting imperatives: "the constraints of the Stability and Growth Pact, and the demands of other parts of the public sector - unemployment benefits, active labor market policies, poverty relief, and policies to address social exclusion, pensions, healthcare, and school education. The resources to finance mass, high-quality higher education from taxation were simply not there" (Barr, 2005, p. 243). One of the implications of the above determining factor was huge demand-absorbing growth of the private sector in several transition systems, including Polish, Bulgarian, Romanian, Lithuanian, as well as Russian and Ukrainian (Kwiek, 2013b).
} 
the communist period, second, there were internal pressures to survive in the turmoil of economic "shock therapies" of the beginning of the 1990s and beyond and in the midst of fundamental financial austerity (incomparable with the situation in the 1970s and the 1980s under communism). And, third, there were internal and exogenous pressures to design and employ new rules and organized practices, responding to the three guiding principles of the reforms in the early 1990s: academic democracy, academic freedom and institutional autonomy. Transformations of universities in the 1990s were specific in kind, and distant from those designed and ongoing in Western Europe.

In the times of the possible reformulation of most generous types of welfare state regimes in Europe (Powell \& Hendricks, 2009; Palier, 2010a; Häusermann, 2010), higher education institutions and systems in the next decade should be able to balance the negative financial impact on the levels of public funding for higher education of the possible gradual restructuring of the public sector. And overall trends in welfare state restructuring seem relatively similar worldwide, as Paul Pierson stressed already a decade ago, long before the recent financial crisis came: "while reform agendas vary quite substantially across regime types, all of them place a priority on cost containment" (Pierson, 2001, p. 456). Or as Castles et al. (2010) highlight in their "Introduction" to a recent handbook on the welfare state in a similar vein, the two decades of neoliberal intellectual attack "increasingly challenged the optimistic faith in the beneficial effects of big government on which the post-war welfare state consensus had rested". In the context of mature welfare states in the European Union, the deepening of European integration "not only imposed constraints on fiscal and monetary policy, which precluded the practice of traditional Keynesian macroeconomic policies at the national level, it also created 'semi-sovereign' welfare states which became imbedded in an emerging multilevel social policy regime" Castles et al. (2010, p.11). The same effects are felt in new EU member states.

In the case of higher education, the economic outlook of the sector "vis-à-vis the intensification of competing social needs, is ever more problematic" (Schuster, 2011, p. 3). The competition for tax funding between various social needs and different public services is bound to grow, regardless of the fact when the current financial crisis will be overcome. The reason is simple, as both students of welfare and students of demography show: European welfare state regimes were created mostly for the "Golden age" period of the European welfare state model, or a quarter of a century between the 1950s and the oil shock of the early 1970s: "taking a long-term view, we can say that this was a most unusual period" (Lutz \& Wilson, 2006, p.13). As Powell and Hendricks argue in the context of welfare states in post-industrial societies $(2009$, p. 10),

nation-states must balance the demands of competing claimants - leaving them with fewer options, but to make hard choices. ... Societal-level redefinitions of what is fair and just are a common means to solutions that do not always do well for citizens in need of assistance, undermining personal sense of security and identity as well as social solidarity.

While the cost containment may be the general state response to financial austerity across European countries, seeking new external revenues may increasingly be an institutional response to the financial crisis on the part of higher education institutions. It was already a response of impoverished universities in most Central and Eastern European economies in 
the 1990s. Certainly, the introduction of fees or their higher levels will be in the spotlight in most systems in which universities will be seeking additional non-state funding (Kwiek, 2010; Kwiek, 2013b). The postwar (Continental) European tradition was tax-based higher education, and (high-level) fees still look non-traditional in most systems.

Trends in European demographics (especially the aging of European societies, see a decade-long OECD series of books: Public Pensions Series) will be affecting directly the functioning of the welfare state (and public sector institutions) in general, with strong country-specific variations. In most European countries, demographics will be affecting universities only indirectly, through the growing pressures on all public expenditures in general, and growing competition for all public funding. In some countries, such as several countries in Central Europe (especially Bulgaria, Romania, Poland, Hungary and Slovakia; and Poland, with powerfully declining demographics, facing projections of the number of students dwindling between 2008 and 2025 by one million, Kwiek, 2012b; Kwiek, 2013b; Antonowicz, 2012), the indirect impact on all public services will be combined with the direct impact on educational institutions. Strong higher education institutions under the combination of unfavorable circumstances will be able to steer the future changes in funding patterns for higher education in their countries. But steering the future changes is becoming an increasingly arduous task, especially that the academic faculty is usually a heavily divided interest group.

\section{Towards a common postcommunist social model in Central Europe?}

Questions about types of welfare states in Central and Eastern Europe are essential because postcommunist countries inherited the social model(s) unknown in Western Europe. They do not fit the classic Esping-Andersen's tripartite division. ${ }^{9}$ Esping-Andersen (1990), creating his typology, for clearly historical reasons, paid almost no attention to Central and Eastern Europe, and political sciences in Western Europe generally did not analyze emergent postcommunist welfare states ${ }^{10}$. Similarly, universities in Central Europe were not included in any major typologies of university governance and organization, typically formed between the 1980s and the 2000s (for instance, by Burton R. Clark, Robert Birnbaum, Johan P. Olsen or Tony Becher and Maurice Kogan). This is a serious theoretical drawback for any

\footnotetext{
${ }^{9}$ As Leibfried and Mau pointed out recently about the unclear usefulness of the regime typology to understanding welfare state transformations in postcommunist countries $(2008, \mathrm{p}$. $\mathrm{xx}$, emphasis in original): "Eastern European countries were seldom included in comparative welfare state research. This was partly due to the lack of comparative data, partly due to the fundamentally different character of the systems. After the fall of Communism, governments in these countries had to balance the need to manage the transition from a command to a market economy with the need to maintain or enhance social protection and thus legitimize regime change. Though these countries went through common phases of transition, they did not arrive at one single model but diversified, with some countries already close to Western welfare states and others still disintegrated. For this reason it also seems questionable whether the regime typology provides an adequate framework for understanding post-Communist welfare state development in Eastern Europe."

${ }^{10}$ Exceptions include Barr, 1994; Barr, 2005; Fenger, 2007; Inglot, 2008; Haggard \& Kaufman, 2008; Cerami 2006; Cerami \& Vanhuysse, 2009; Szelenyi \& Wilk, 2010; Ferge, 2008; Cook, 2007 and others.
} 
international comparative higher education research or any international comparative welfare research with reference to Central and Eastern Europe today, though. ${ }^{11}$ Because the region was clearly "a virtual laboratory of experimentation" (Esping-Andersen, 1996, p. 267), it was not easy to accommodate its welfare states to any existing typologies.

In the Esping-Andersen's tradition of "worlds of welfare", it is methodologically improper to merely add a fourth type, a "postcommunist welfare state", without rethinking the whole three-type configuration of liberal, conservative, and social-democratic welfare regimes. So far, there have been limited attempts at integrating the new EU member states into the common framework provided by the three worlds of the welfare capitalism research. ${ }^{12}$ As Schubert et al. argue about extending existing typologies,

[t]he addition of a new type of welfare regime or cluster affects the existing typology, since ... the danger exists that differences within the regimes could be greater than between them. Methodically speaking, it would be inadmissible to add a new cluster to an exiting cluster analysis without reassessing the overall ratio of the individual elements. ... Therefore, new elements cannot be added without new analyses. With the enlargement of the EU, the longused empirical basis of the typology welfare regimes is eroding (Schubert et al., 2009b, p. 15).

We must also remember that "the welfare state does not follow a unified logic, nor do its reforms", and in this sense the European landscape and the systems themselves, as well as their reforms, are extremely diverse (Leibfried, 2001, p. 5). In a similar vein, Central European higher education systems escape traditional typologies of university governance and organization and are extremely diverse as well.

\footnotetext{
${ }^{11}$ The most important books analyzing the transformation of social policy and labor markets in Central Europe are still the two volumes by Nicholas Barr (1994 and 2005). One of the first books devoted entirely to historical diversities of Central European welfare states was Tomasz Inglot's Welfare states in East Central Europe, 1919-2004 (Inglot, 2008; see also an earlier book by Alfio Cerami, Social policy in Central and Eastern Europe. The Emergence of a new European welfare regime, 2006). Inglot describes post-communist types of the welfare state ("emergency welfare states") as not only differing from those analyzed in the research literature on European basic welfare state types but also, paradoxically, seriously differing among themselves. Furthermore, their future remains undefined, they are "work in progress" (Inglot, 2008, p. 8). In contrast, Haggard and Kaufman (2008) highlight the intra-regional commonalities. See also a recent comparative volume grounded in historical institutionalism, recently edited by Alfio Cerami and Pieter Vanhuysse (2009): Post-communist welfare pathways. Theorizing social policy transformations in Central and Eastern Europe which contributes to discussions about the specificity of postcommunist welfare regimes focusing on questions of unity, diversity, path-dependence and path-departure. The conclusions are that the emergent postcommunist welfare models are hybrids, "a joint outcome of 'the past' and 'the West'" (Offe, 2009, p. 237).

${ }^{12}$ In the "beyond varieties of capitalism" research, there appear "capitalism goes East" sections, see especially King, 2007; see also Hancké, 2009, pp. 290-293, for a "revised typology of capitalist varieties"; and in the original formulation of the "families of nations" research (Castles, 1993), clearly referring to "patterns of public policy in Western democracies", postcommunist economies do not appear, Castles and Mitchell, 1993, p. 93; for the first time, postcommunist countries are incorporated in this tradition as a "new postcommunist family of nations" in Castles \& Obinger (2008).
} 


\section{Final remarks}

Higher education systems and welfare systems in Central Europe are still in transition, despite 20 years of changes in progress. Taking Poland as an example, one concludes that indeed (following Nils Brunsson, Johan P. Olsen and other institutionalists in organizational studies) reforms in both areas lead to new reforms rather than to finally "reformed" systems. Higher education governance and funding was substantially changed in the 2008-2011 reform period, and funding for the two largest pillars of the welfare state, pensions and healthcare, is still under permanent revisions. New reforms inevitably invoke still newer reforms, and their directions are fundamentally unclear (Kwiek, 2013a). For about a decade, privatization was the major trend in both higher education, pensions and healthcare. In the last few years, there is a new powerful trend of de-privatization, though. Public universities are becoming ever more reliant on public funding, 80 percent of private higher education institutions are expected to disappear within a decade, the share of private sector students is expected to shrink from the peak of about 34 percent in 2008 to about 12 percent in 2022 due to changing demographics and the expansion of tax-based public higher education; de-privatization of the pension system means a gradual retreat from a multi-pillar system introduced in 1999 and a (possible) return to a publicly-funded one-pillar system with a marginal role played by private pension funds. So the reforms of the 1990s leading to privatization are followed by current reforms leading to de-privatization in both areas.

From this perspective, it is too risky to suggest generalizations about how Central European higher education or welfare systems fit existing typologies or how to extend existing typologies to embrace the region. The "transition" period is by no means over: it is over in terms of politics (strong liberal democracies) and economics (open market economies) but not in terms of social arrangements. Both higher education and welfare states are "work in progress": permanently under reform pressures, with unclear future. ${ }^{13}$

\section{References}

Aidukaite, J. (2009). Old welfare state theories and new welfare regimes in Eastern Europe: Challenges and implications. Communist and Post-Communist Studies, 42.

Antonowicz, D. (2012). External influences and local responses. Changes in Polish higher education 1990-2005. In M. Kwiek \& P. Maassen, (Eds.), National higher education reforms in a European context: Comparative reflections on Poland and Norway. Frankfurt and New York: Peter Lang.

Balcerowicz, L. (1996). Socialism. Capitalism. Transformation. Budapest: Central European University Press.

Barr, N. (2004). Economics of the welfare state (4th ed.). Oxford: Oxford University Press.

Barr, N. (Ed.). (1994). Labor markets and social policy in Central and Eastern Europe. The transition and beyond. Oxford: Oxford UP.

Barr, N. (Ed.). (2005). Labor markets and social policy in Central and Eastern Europe. The accession and beyond. Oxford: Oxford UP.

Becher, T., \& Kogan, M. (1980). Process and structure in higher education. London: Heinemann.

${ }^{13}$ Acknowledgements. The author gratefully acknowledges the support of the National Research Council (NCN) through its MAESTRO grant DEC-2011/02/A/HS6/00183 (2012-2017). 
Brunsson, N. (2009). Reform as routine: Organizational change and stability in the modern world. New York: Oxford University Press.

Campbell, J. L. (2004). Institutional change and globalization. Princeton: Princeton University Press.

Castles, F. G. (1993). Introduction. In F. G. Castles (Ed.), Families of nations: patterns of public policy in western democracies. Aldershot: Dartmouth Publishing Company. xiii-xxiii.

Castles, F. G., \& Mitchell, D. (1993). Worlds of welfare and families of nations. In F. G. Castles (Ed.), Families of nations: patterns of public policy in western democracies (pp. 93-128). Aldershot: Dartmouth Publishing Company.

Castles, F. G., Leibfried, S., Lewis, J., Obinger, H., Pierson, C. (2010). Introduction. In F. G. Castles, S. Leibfried, J. Lewis, H. Obinger \& C. Pierson (Eds.), The Oxford handbook of the welfare state (pp. 1-15). New York: Oxford University Press.

Castles, F. G., \& Obinger, H. (2008). Worlds, families, regimes: On the coherence and persistence of country clusters in European and OECD area public policy. West European Politics, 31(1-2), 321345.

Cerami, A. (2006). Social policy in Central and Eastern Europe: The emergence of a new European welfare regime. Münster: LIT.

Cerami, A., \& Vanhuysse, P. (Eds.). (2009). Post-communist welfare pathways. New York: Palgrave.

Cook, L. J. (2007). Postcommunist welfare states: Reform politics in Russia and Eastern Europe. Ithaca and London: Cornell University Press.

Delanty, G. (2001). Challenging knowledge. The university in the knowledge society. Buckingham: SRHE and Open University Press.

Djelic, M. L., \& Quack, S. (2012). Transnational governance through standard setting: the role of transnational communities. In G. Morgan \& R. Whitley (Eds.), Capitalisms \& capitalism in the twenty-first century (pp. 166-189). Oxford: Oxford University Press

Elster, J., Offe, C., \& Preuss, U.K. (1998). Institutional design in post-communist societies: Rebuilding the ship at sea. Cambridge: Cambridge University Press.

Esping-Andersen, G. (1996). After the golden age? Welfare state dilemmas in a global economy. In G. Esping-Andersen (Ed.), Welfare states in transition: National adaptations in global economies (pp. 1-31). London: SAGE.

Esping-Andersen, G. (1990). The three worlds of welfare capitalism. Princeton: Princeton University Press.

Feigenbaum, H., Henig, J., \& Hamnett, C. (Eds.). (1998). Shrinking the state. The political underpinnings of privatization. Cambridge: Cambridge University Press.

Fenger, H.J.M. (2007). Welfare regimes in Central and Eastern Europe: Incorporating post-communist countries in a welfare regime typology. Contemporary Issues and Ideas in Social Sciences, 3(2).

Ferge, Z. (2001). European integration and the reform of social security in the accession countries. The European Journal of Social Quality, 3(1-2).

Ferge, Z. (2008). Is there a specific East-Central European welfare culture. In W. van Oorschot, M. Opielka \& B. Pfau-Effinger (Eds.), Culture and welfare state: values and social policy in comparative perspective. Cheltenham: Edward Elgar.

Ferrera, M. (2003). Reforming the European social model: Dilemmas and perspectives. The European legacy, $8(5)$.

Foray, D. (2006). The economics of knowledge. Cambridge, MA: the MIT Press.

Gornitzka, A. (2007). The Lisbon process: A supranational policy perspective. In P. Maassen \& J.P. Olsen (Eds.), University dynamics and European integration (pp.155-180). Dordrecht: Springer.

Gornitzka, A., \& Maassen, P. (2011). University governance reforms, global scripts and the "Nordic Model". Accounting for policy change? In J. Schmid, K. Amos, J. Schrader \& A. Thiel (Eds.), Welten der Bildung? Vergleichende Analysen von Bildungspolitik und Bildungssystemen (pp. 149-177). Baden Baden: Nomos Verlagsgesellschaft. 
Goodin, R. E. (Ed.). (1996). The theory of institutional design. Cambridge: Cambridge University Press.

Haggard, S., \& Kaufman, R.R. (2008). Development, democracy and welfare states: Latin America, East Asia, and Eastern Europe. Princeton: Princeton University Press.

Hancké, B. (Ed.). (2009). Debating varieties of capitalism: A Reader. New York: Oxford University Press.

Häusermann, S. (2010). The politics of welfare state reform in continental Europe: Modernization in hard times. Cambridge: Cambridge University Press.

Hay, C., Lister, M., \& Marsh, D. (Eds.). (2006). The state: Theories and issues. Houndmills: Palgrave Macmillan.

Held, D., \& McGrew, A. (Eds.). (2007). Globalization theory. Approaches and controversies. Cambridge: Polity Press.

Hurrelmann, A., Leibfried, S., Martens, K., \& Mayer, P. (Eds.). (2007a). Transforming the golden-age nation state. Basingstoke: Palgrave Macmillan.

Hurrelmann, A., Leibfried, S., Martens, K., \& Mayer, P. (2007b). The golden-age nation state and its transformation: A framework for analysis. In A. Hurrelmann, S. Leibfried, K. Martens \& P. Mayer (Eds.). Transforming the golden-age nation state. Basingstoke: Palgrave Macmillan.

Inglot, T. (2008). Welfare states in East Central Europe 1919-2004. Cambridge: Cambridge University Press.

Jakobi, A.P., Martens, K., \& Wolf, K.D. (Eds.). (2010a). Education in political science: Discovering a neglected field. London: Routledge.

King, L. P. (2007). Central European capitalism in comparative perspective. In B. Hancké, M. Rhodes, \& M. Thatcher (Eds.), Beyond varieties of capitalism: Conflict, contradictions, and complementarities in the European economy (pp. 308-327). New York: Oxford University Press.

Kogan, I., Noelke, C., \& Gebel, M. (Eds.). (2011). Making the transition: Education and labor market entry in Central and Eastern Europe. Stanford: Stanford University Press.

Kwiek, M. (2005). The university and the state in a global age: Renegotiating the traditional social contract? European Educational Research Journal, 4(4), 324-341.

Kwiek, M. (2006). The university and the state. A study into global transformations. Frankfurt a/Main and New York: Peter Lang.

Kwiek, M. (2007). The university and the welfare state in transition: Changing public services in a wider context. In D. Epstein, R. Boden, R. Deem, F. Rizvi, \& S. Wright (Eds.), World yearbook of education 2008 (pp. 32-50). New York: Routledge.

Kwiek, M. (2009). Globalization: Re-reading its impact on the nation-state, the university, and educational policies in Europe. In M. Simons, M. Peters \& M. Olssen (Eds.), Re-reading education policies: studying the policy agenda for the 21st century (pp. 195-215). Rotterdam/Boston/Taipei: Sense Publishers.

Kwiek, M. (2010). Creeping marketization: Where Polish private and public higher education sectors meet. In R. Brown (Ed.), Higher education and the market (pp.135-146). New York: Routledge.

Kwiek, M. (2011). Universities and knowledge production in Central Europe. In P. Temple (Ed.), Universities in the knowledge economy. Higher education organisation and global change (pp. 176-195). New York: Routledge.

Kwiek, M. (2012a). Changing higher education policies: From the deinstitutionalization to the reinstitutionalization of the research mission in Polish universities. Science and Public Policy, 39, 641-654.

Kwiek, M. (2012b). The growing complexity of the academic enterprise in Europe: A panoramic view. European Journal of Higher Education, 2(2-3), 112-131.

Kwiek, M. (2012c). Universities, regional development and economic competitiveness: the Polish case. In R. Pinheiro, P. Benneworth \& G. Jones (Eds.), Universities and regional development. A critical assessement of tensions and contradictions (pp. 69-85). New York: Routledge 
Kwiek, M. (2013a). Knowledge production in European universities. States, markets, and academic entrepreneurialism. Frankfurt and New York: Peter Lang.

Kwiek, M. (2013b). From system expansion to system contraction: Access to higher education in Poland. Comparative Education Review, 57(3), 553-576.

Kwiek, M. \& Maassen, P. (Eds.). (2012). National higher education reforms in a European context. Comparative reflections on Poland and Norway. Frankfurt and New York: Peter Lang.

Lane, D. (Ed.). (2007a). The transformation of state socialism: System change, capitalism or something else? Basingstoke: Palgrave Macmillan.

Lane, D., \& Myant, M. (Eds.). (2007). Varieties of capitalism in post-communist countries. Basingstoke: Palgrave Macmillan.

Leibfried, S. (Ed.). (2001). Welfare state futures. Cambridge: Cambridge University Press.

Leibfried, S., \& Mau, S. (2008). Welfare states: construction, deconstruction, reconstruction. In S. Leibfried \& S. Mau (Eds.), Welfare states: Construction, deconstruction, reconstruction. Volume I: Analytical Approaches (pp. xi-lxiv). Cheltenham: Edward Elgar.

Lutz, W., \& Wilson, C. (2006). Introduction. In W. Lutz, R. Richter \& C. Wilson (Eds.), The new generations of Europeans: Demography and families in the enlarged European Union (pp. 3-17). London: Earthscan.

Maassen, P., \& Olsen, J.P. (Eds.). (2007). University dynamics and European integration. Dordrecht: Springer.

March, J. G., \& Olsen, J. P. (2006). Elaborating the "New Institutionalism". In R.A.W. Rhodes, S.A. Binder \& B. A. Rockman (Eds.), The Oxford handbook of political institutions (pp. 3-20). Oxford: Oxford University Press.

Martens, K. (2007). How to become an influential actor - the "comparative turn" in OECD education policy. In K. Martens, A. Rusconi \& K. Leuze (Eds.), New arenas of education governance: The impact of international organizations and markets on educational policy making (pp. 40-56). Basingstoke: Palgrave Macmillan.

Martens, K., \& Jakobi, A. P. (Eds.) (2010a). Mechanisms of OECD governance: International incentives for national policy-making? Oxford: Oxford University Press.

Mateju, P., Rehakova, B., \& Simonova, N. (2007). The Czech Republic: structural growth of inequality in access to higher education. In Y. Shavit, R. Arum \& A. Gamoran (Eds.), Stratification in higher education. A comparative study (pp. 374-399). Stanford: Stanford University Press.

Noelke, C., \& Müller, W. (2011). Social transformation and education systems in Central and Eastern Europe. In I. Kogan, C. Noelke \& M. Gebel (Eds.), Making the transition: Education and labor market entry in Central and Eastern Europe (pp. 1-28). Stanford: Stanford University Press.

Offe, C. (1996a). Varieties of transition: The East European and East German experience. Cambridge: Polity Press.

Offe, C. (1996b). Designing institutions in East European transitions. In R. E. Goodin (Ed.), The theory of institutional design (pp. 199-226). Cambridge: Cambridge University Press.

Offe, C. (2009). Epilogue: Lessons learnt and open questions. In A. Cerami \& P. Vanhuysse (Eds.), Post-communist welfare pathways (pp. 237-248). New York: Palgrave.

Orenstein, M. A. (2008). Postcommunist welfare states. Journal of Democracy, 19(4), 80-94.

Orenstein, M. A. (Ed.). (2009). Pensions, social security, and the privatization of risk. New York: Columbia University Press.

Orenstein, M. A., \& Haas, M. R. (2005). Globalization and the future of welfare states in postcommunist East-Central European countries. In M. Glatzer \& D. Rueschemeyer (Eds.), Globalization and the future of the welfare state (pp. 130-152). Pittsburgh: University of Pittsburgh Press.

Palier, B. (Ed.). (2010a). A long goodbye to Bismarck? The politics of welfare reform in continental Europe. Amsterdam: Amsterdam University Press. 
Pierson, P. (1994). Dismantling the welfare state? Reagan, Thatcher, and the politics of retrenchment. Cambridge: CUP.

Pierson, P. (2001b). Coping with permanent austerity: Welfare state restructuring in affluent democracies. In P. Pierson (Ed.), The new politics of the welfare state. Oxford: Oxford UP.

Powell, J., \& Hendricks, J. (Eds.). (2009). The welfare state in post-industrial society. A global perspective. Dordrecht: Springer.

Przeworski, A. (1991). Democracy and the market: Political and economic reforms in Eastern Europe and Latin America. Cambridge: CUP.

Rama, M. (2000). Public sector downsizing: An introduction. The World Bank Economic Review, 13(1).

Rothgang, H., Cacace, M., Frisina, L., Grimmeisen, S., Schmid, A., \& Wendt, C. (2010). The state and healthcare: Comparing OECD countries. Basingstoke: Palgrave Macmillan.

Sachs, J. (1994). Life in the economic emergency room. In J. Williamson (Ed.), The political economy of policy reforms (pp. 501-524).Washington DC: Institute for International Economics.

Schubert, K., Hegelich, S., \& Bazant, U. (2009b). European welfare systems: Current state of research and some theoretical considerations. In K. Schubert, S. Hegelich \& U. Bazant (Eds.), The handbook of European welfare systems (pp. 3-28). London: Routledge.

Schuster, J. H. (2011). The professoriate's perilous path. In J. C. Hermanowicz (Ed.), The American academic profession. Transformations in contemporary higher education (pp. 21-43). Baltimore: the Johns Hopkins University Press.

Simmons, B. A., Dobbin, F. \& Garret, G. (Eds.). (2008). The global diffusion of markets and democracy. Cambridge: Cambridge University Press.

Sipilä, J., Anttonen, A., \& Kröger, T. (2009). A Nordic welfare state in a post-industrial society. In J. Powell \& J. Hendricks (Eds.), The welfare state in post-industrial society. A global perspective (pp. 181-200). Dordrecht: Springer.

Spulber, N. (1997). Redefining the state: Privatization and welfare reform in industrial and transitional economies. Cambridge, England: Cambridge University Press.

Stehr, N. (2002). Knowledge and economic conduct. The social foundations of the modern economy. Toronto: University of Toronto Press.

Suleiman, E. (2003). Dismantling democratic states. Princeton: Princeton University Press.

Szczepanski, J. (1974). Higher education in Eastern Europe. New York: International Council for Educational Development.

Szelenyi, I., \& Wilk, K. (2010). Institutional transformation in European post-communist regimes. In G. Morgan, J. L. Campbell, C. Crouch, O. K. Pedersen \& R. Whitley (Eds.), The Oxford handbook of comparative institutional analysis (pp. 565-585). New York: Oxford University Press.

Tanzi, V. (2011). Government versus market: The changing economic role of the state. Cambridge: Cambridge University Press.

Woodward, R. (2009). The Organisation for Economic Co-operation and Development (OECD). London: Routledge.

Center for Public Policy Studies

UNESCO Chair in Institutional Research and Higher Education Policy,

University of Poznan,

ul. Szamarzewskiego 89, 60-569,

Poznan, Poland

E-mail: kwiekm@amu.edu.pl 